\title{
Evaluation of the efficiency of the three-way catalytic converter of a spark ignition engine of the chosen aromatic hydrocarbons removing
}

In the paper the results of measurement of the most popular aromatic hydrocarbons (benzene, toluene and xylenes) in the exhaust of spark ignition engine before and after three-way catalytic reactor were presented. The investigations have been conducted at fixed rotational speed, $2500 \mathrm{rpm}$ and at a few different values of torque in range $0-80 \mathrm{Nm}$, every $10 \mathrm{Nm}$. Based on obtained results, the calculations of catalytic reactor efficiency in removing analysed components have been made. The measurements showed high efficiency of the catalytic converter in reduction of that pollutants in exhaust gases.

Key words: hydrocarbons, TWC, exhaust, BTX, spark ignition engines

\section{Introduction}

Photochemical air pollution is mostly caused by volatile organic compounds (VOCs) from vehicle evaporative emissions. The most significant way of VOCs emissions by vehicle is tailpipe effect, which is characterized by expulsion from the system a large amount of unburned fuel vapours and exhaust fumes from fuel combustion generated during engine operation. Another cause of VOCs emission is evaporative impact, which results in vaporization of fuels regardless of whether the vehicle is moving or not. In addition, volatile organic compounds are emitted from vehicle equipment, such as leather seats, plastics and tires [1]. Generally, the composition of exhaust gases depends on many factors, one of them is type of an engine and its ignition. Self-ignition and spark-ignition have influence on concentration of low boiling hydrocarbons (the greater part of volatile organic compounds) and another gaseous toxic compounds of exhaust gases and solid particles with the fact that higher concentration of VOCs and lower solid particles emission is typical for spark-ignition engines [2]. Main reason of such a state of affairs is less gasoline tendency to create soot regard to diesel fuel [3]. In case of VOCs concentration, it is determined by the course of combustion process which consists complex chemical and physical reactions and phenomena. The best option in this case is total combustion, which prevents the unburned hydrocarbons escape from the system. The impact on these processes has composition of air-fuel mixture in the combustion chamber characterized by the air-fuel ratio $\lambda$ [4]. The airfuel ratio in spark-ignition engines closely determines fuel consumption, power, and also exhaust composition in each state of engine's operation. Rich mixture of air-fuel composition $(\lambda<1)$, when the oxygen level is low, causes increased number of unburned hydrocarbons. As the amount of air increases $(\lambda>1)$ the combustion of hydrocarbons is more effective, simultaneously temperature inside combustion chamber increases as well, which supports termination of the reactions, as shown in Fig. 1 [3].

From one year to another increase in the concentration of VOCs in the environment due to the increasing number of total vehicles has major impact on formation of surface ozone [5] and secondary organic aerosols (SOAs) [6].
However, particular importance has their direct toxicity on human health and all living organism in general. The most hazardous compounds from VOCs group are low boiling single aromatic hydrocarbons shown in figure 2 , such as benzene, toluene and xylene isomers, known as BTX group [7]. BTX group consists single aromatic hydrocarbons which exist mainly in the gasoline fraction of the petroleum hydrocarbons that mostly are emitted with exhausts from automobiles [8].

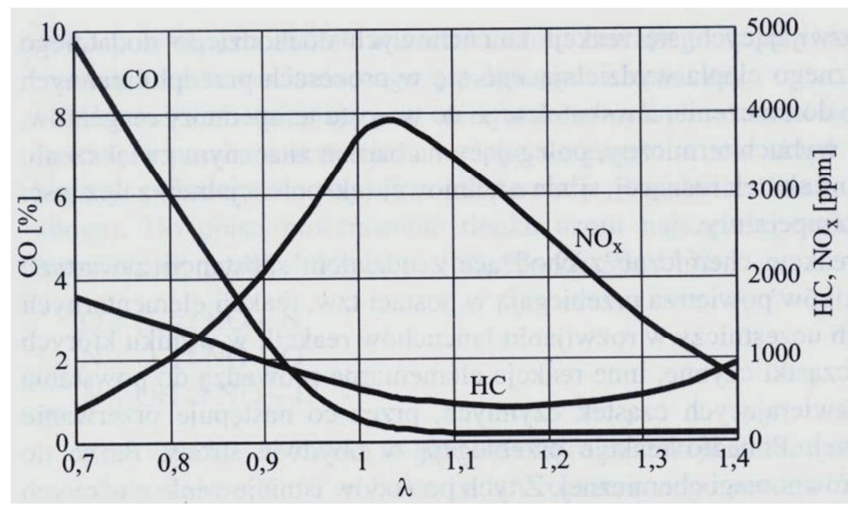

Fig. 1. Carbon monoxide $\mathrm{CO}$, hydrocarbons $\mathrm{HC}$ and nitrogen oxides $\mathrm{NO}_{\mathrm{x}}$ concentration values depending on the air-fuel ratio [3]
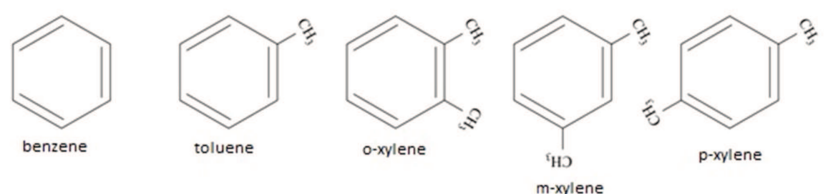

Fig. 2. Skeletal formulas of aromatic hydrocarbons molecules belonging to BTX group

The BTX group is highly toxic, especially benzene. Due to its specific chemical and physical properties, as shown in Table 1, exposure to the BTX group is constantly human health concern. Because of facilitated inhalation of these volatile compounds the health effects begin with general distress (drowsiness, headaches, dizziness) to more severe anomalies in the living organism. Within the long exposure to these compounds BTX group appears to be mutagenic and carcinogenic for the cells of respiratory system [9]. 
Table 1. Physical and chemical properties of BTX group [10]

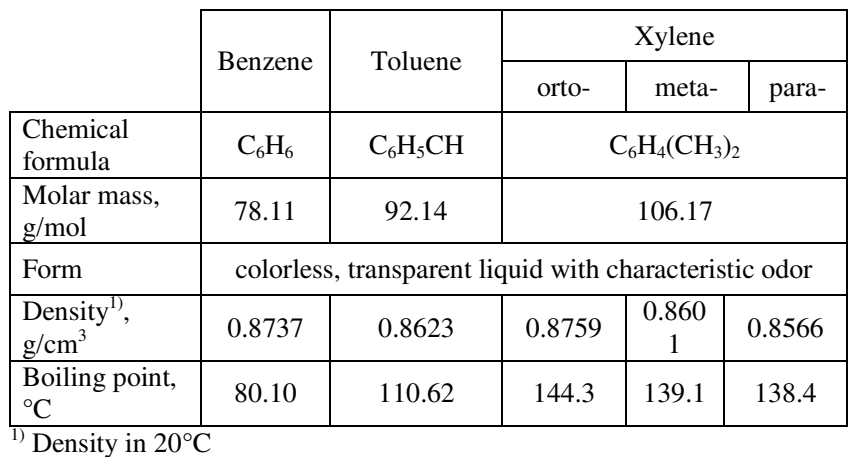

Because of the harmfulness of BTX group and other components of combustion fumes in general there is many methods of exhaust purification. Under real conditions of engine operation it is not possible to achieve adequate reaction rate therefore catalytic reactors are used to accelerate certain processes. Nowadays three-way catalytic reactors (TWC) are used for spark-ignition engines due to their possibility to remove three group of the most harmful compounds (carbon monoxide $\mathrm{CO}$, hydrocarbons $\mathrm{HC}$ and nitrogen oxides $\mathrm{NO}_{\mathrm{x}}$ ) [11]. The principle of this type of catalytic reactors operation is based on the support for carbon monoxide and hydrocarbons conversion (oxidation) to non-toxic carbon dioxide as a result of total combustion while the group of nitrogen oxides is simultaneously converted to nitrogen and oxygen (reduction) [3]. Efficiency of TWC depends on many factors, especially its temperature, concentration of pollutants and time of contact with active layer. Temperature of reliable work of catalytic converter is between 250 and $900^{\circ} \mathrm{C}$, and the maximum temperature is about $1100-1200^{\circ} \mathrm{C}[11]$.

\section{Material and methods}

The tests of three-way catalytic reactor (TWC) efficiency were conducted on the spark-ignition engine Fiat 1.2 on the engine test bench in the Department of Automotive Engineering, Wroclaw University of Science and Technology. It was 4 cylinders and 8 valves, multipoint injection and natural aspirated engine with maximum power $46 \mathrm{~kW}$ at $5500 \mathrm{rpm}$ and maximum torque $105 \mathrm{Nm}$ at $3200 \mathrm{rpm}$. The engine was used in the passenger cars such as Fiat Brava or Fiat Punto. The tested engine was coupled by the shaft with the water-cooled electromagnetic brake EMX 100/10000, which allowed applying the engine torque. In Figure 3 the test station was presented. The catalytic reactor was located at the exhaust manifold just after the cylinder outlet.

In the tests the engine was powered by the commercial gasoline with 95 octane number. Before investigations began, it was needed to wait when the engine and the catalyst reactor would achieve their operating temperature. In the tests load characteristic of engine with fixed rotational speed was performed. The rotational speed was set on the $2500 \mathrm{rpm}$ value. The engine was loaded with the torque values from 0 to $80 \mathrm{Nm}$ every $10 \mathrm{Nm}$. Samples were taken in almost the same time before and after TWC by special measuring connectors. After setting the next value of torque, it was needed to wait above 10 minutes before sam- pling for achieving the suitable temperature of catalytic reactor. Changing the engine's torque with constant rotational speed in spark ignition engine, the temperature of the combustion process and thus the temperature of exhaust fumes changes as well. Beside concentrations of BTX, additionally in the tests fuel consumption (in $\mathrm{g} / \mathrm{s}$ ) was measured.

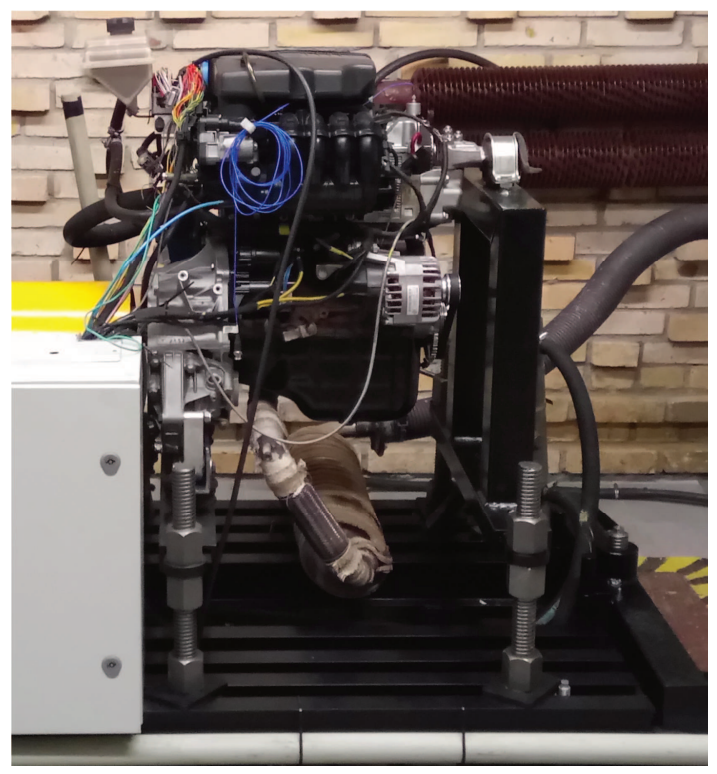

Fig. 3. The engine test station, Fiat 1.2

Concentrations of the aromatic hydrocarbons from BTX group were analysed using gas chromatography method. The samples of the fumes before and after TWC were taken to Teflon bags by the vacuum pump. It allowed for shortterm BTX concentration measurement. Then, the content of the bags was given by semi-automatic aspirator ASP-3II into special tubes filled with active carbon. The aspirator was equipped with the pomp and flow controller. From each bag $10 \mathrm{dm}^{3}$ of exhausts were transferred with a fixed airflow rate set at $30 \mathrm{dm}^{3} / \mathrm{h}$. Setting the same value of airflow and the fumes volume in each of samples enabled comparing the concentrations before and after TWC without any additional calculations. All samples were moved to the Laboratory of Emission Researches in the Department of Automotive Engineering, Wroclaw University of Science and Technology, where were analysed with a gas chromatography (GC) method.

In the Laboratory tube samples were prepared for further steps. The sorbent (active carbon) with fumes adsorbed on its surface was extracted from each tube correspondingly to $5 \mathrm{ml}$ flasks. To the flasks was added $2 \mathrm{ml}$ of carbon disulphide solvent and the flasks were tightly closed. The extraction proceeded for 20 minutes, including 5 minutes extraction inside ultrasound generator chamber in temperature about $30^{\circ} \mathrm{C}$. After 20 minutes each solution from over active carbon particles was moved respectively to $10 \mathrm{ml}$ flask and attentively purified from carbon dust. For qualitative and quantitative analysis gas chromatograph Varian 450-GC with FID detector, autosampler and proper capillary column was used. On the chromatography column a 
clear solutions were given at an established internal method for VOCs analysis, as follow:

- dispenser temperature: $200^{\circ} \mathrm{C}$,

- oven and capillary column temperature program: $110^{\circ} \mathrm{C}$, 10 minutes, isothermal program,

- FID detector temperature: $250^{\circ} \mathrm{C}$.

\section{Results}

As a results of gas chromatography analysis are concentration of aromatic hydrocarbons in ppm in solvent $\left(\mathrm{CS}_{2}\right)$. It was necessary to calculate these values for concentrations in the exhaust in $\mu \mathrm{g} / \mathrm{m}^{3}$. The calculations were made using the equation as follow:

$$
\mathrm{C}_{\mu \mathrm{g}} \mathrm{m}^{3}=\frac{2 \cdot \mathrm{C}_{\mathrm{ppm}} \cdot 1,26 \cdot 10^{-3}}{0,8 \cdot \mathrm{V}}
$$

where: 2 - volume of solvent used in desorption, in $\mathrm{cm}^{3}$, Cppm - concentration in ppm in solvent, 1,26 - density of $\mathrm{CS} 2$, in $\mathrm{g} / \mathrm{cm}^{3}, 0,8$ - error of desorption, $\mathrm{V}$ - volume of air, $\mathrm{dm}^{3}$

Calculations have been made for the values of concentrations measured before and after catalyst reactor. In table 2 concentrations of analysed aromatic hydrocarbons in $\mu \mathrm{g} / \mathrm{m} 3$ at $2500 \mathrm{rpm}$ are shown. In figure 4 chart of concentrations of BTX before TWC are presented.

Table 2. Concentration (in $\mu \mathrm{g} / \mathrm{m}^{3}$ ) of BTX measured before and after catalyst reactor

\begin{tabular}{|c|c|c|c|c|c|c|c|c|}
\hline \multirow[b]{2}{*}{$\begin{array}{c}\text { Torque, } \\
\mathrm{Nm}\end{array}$} & \multicolumn{4}{|c|}{$\begin{array}{c}\text { Concentration before TWC, } \\
\mathrm{ug} / \mathrm{m}^{3}\end{array}$} & \multicolumn{4}{|c|}{$\begin{array}{c}\text { Concentration after TWC, } \\
\mathrm{ug} / \mathrm{m}^{3}\end{array}$} \\
\hline & $\begin{array}{c}\text { Ben } \\
\text { ze- } \\
\text { ne }\end{array}$ & $\begin{array}{l}\text { Tolu- } \\
\text { ene }\end{array}$ & $\begin{array}{l}\text { Xy- } \\
\text { lenes }\end{array}$ & $\begin{array}{c}\text { Sum } \\
\text { of } \\
\text { BTX }\end{array}$ & $\begin{array}{c}\text { Ben } \\
\text { ze- } \\
\text { ne }\end{array}$ & $\begin{array}{l}\text { Tolu- } \\
\text { ene }\end{array}$ & $\begin{array}{c}\text { Xy- } \\
\text { le- } \\
\text { nes }\end{array}$ & $\begin{array}{c}\text { Sum } \\
\text { of } \\
\text { BTX }\end{array}$ \\
\hline 0 & 7.25 & 22.18 & 10.53 & 44.78 & 1.46 & 4.90 & 5.55 & 14.29 \\
\hline 10 & 5.21 & 15.35 & 8.01 & 32.22 & 1.87 & 7.54 & 7.16 & 19.59 \\
\hline 20 & 5.99 & 18.96 & 10.59 & 40.23 & 1.42 & 4.28 & 4.91 & 12.72 \\
\hline 30 & 1.14 & 4.18 & 3.01 & 9.01 & 0.04 & 0.25 & 0.41 & 0.78 \\
\hline 40 & 1.17 & 4.19 & 2.78 & 8.77 & 0.17 & 0.92 & 1.22 & 2.56 \\
\hline 50 & 1.21 & 4.36 & 3.02 & 9.32 & 0.18 & 1.04 & 1.41 & 2.95 \\
\hline 60 & 0.31 & 1.03 & 0.55 & 2.01 & 0.01 & 0.05 & 0.04 & 0.10 \\
\hline 70 & 1.17 & 3.95 & 2.37 & 8.03 & 0.03 & 0.08 & 0.10 & 0.24 \\
\hline 80 & 0.50 & 1.35 & 0.64 & 2.64 & 0.02 & 0.00 & 0.01 & 0.03 \\
\hline
\end{tabular}

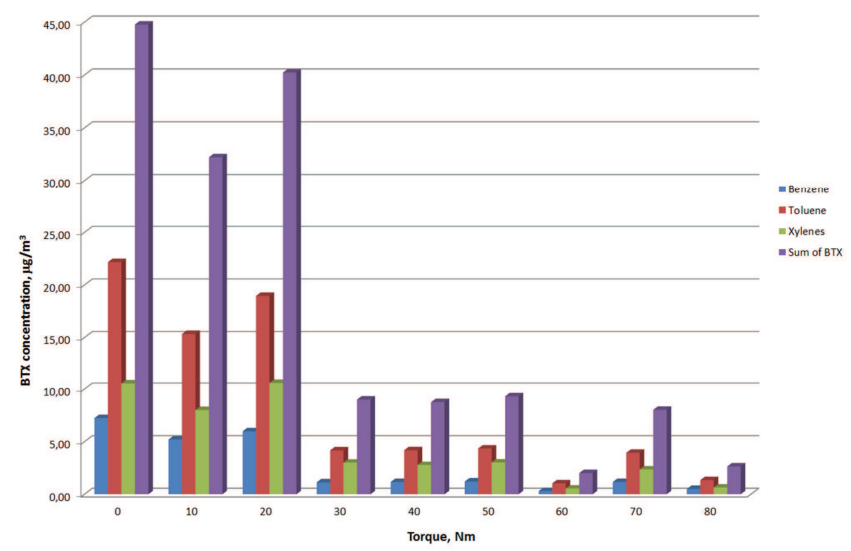

Fig. 4. Concentration of BTX (in $\mu \mathrm{g} / \mathrm{m}^{3}$ ) before catalyst reactor depending on the torque value

As it has been written above, one of the duty of the TWC is oxidation of hydrocarbons to carbon dioxide. In
Figure 5 comparison of the concentrations before and after catalyst reactor on the example of benzene is shown.

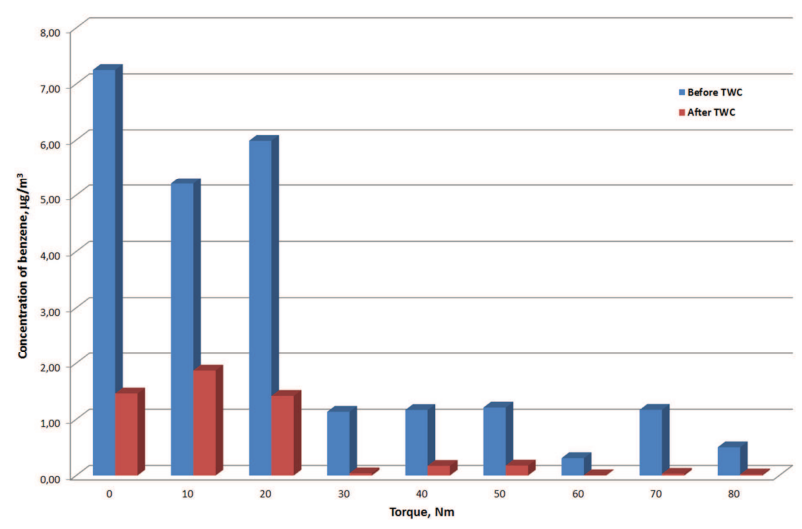

Fig. 5. Concentrations of benzene $\left(\mu \mathrm{g} / \mathrm{m}^{3}\right)$ depending on the torque value before and after three-way catalyst reactor

In next step the efficiency of the three-way catalyst reactor has been determined according to the equation:

$$
\mathrm{E}_{\mathrm{f}}=1-\frac{\mathrm{C}_{\mathrm{a}, \mathrm{i}}}{\mathrm{C}_{\mathrm{b}, \mathrm{i}}} \cdot 100 \%
$$

where: $\mathrm{E}_{\mathrm{f}}$ - efficiency of TWC, $\%, \mathrm{C}_{\mathrm{a}}$ - concentration after $\mathrm{TWC}, \mathrm{ug} / \mathrm{m}^{3}, \mathrm{C}_{\mathrm{b}}$ - concentration before TWC, ug $/ \mathrm{m}^{3}, \mathrm{i}-$ component of $\mathrm{HC}$

Calculated efficiency of analysed TWC for each of measured aromatic hydrocarbons is shown in Figure 6. In Figure 7 the efficiency of the sum of BTX is shown.

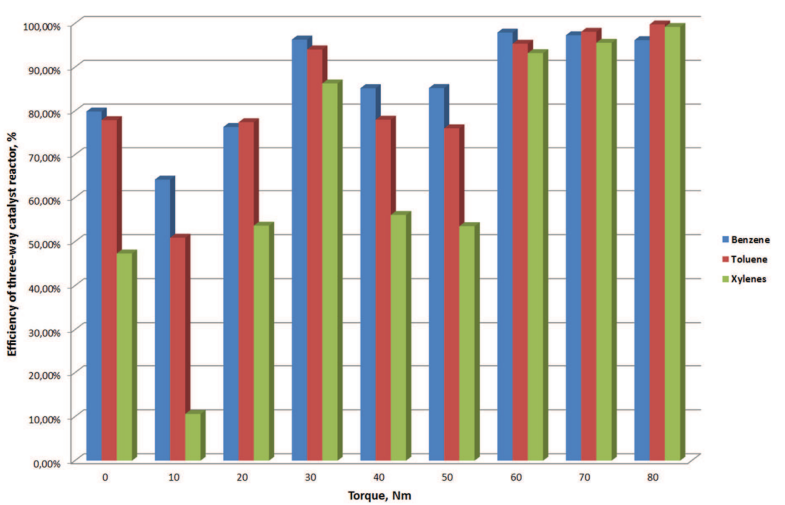

Fig. 6. Effectiveness of analysed aromatic hydrocarbons removal by TWC depending on the torque value

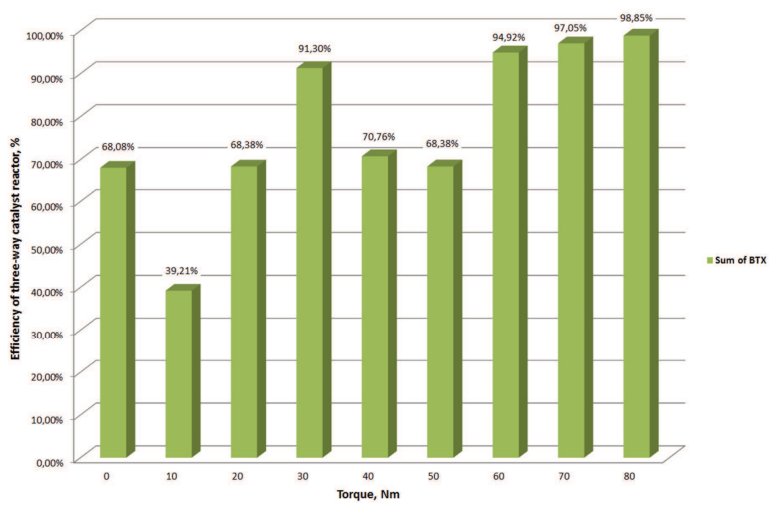

Fig. 7. Effectiveness of sum of BTX removal by TWC depending on the torque value 


\section{Discussions and conclusions}

As it could be seen in Figures 6 and 7, except a few points of engine's work, generally the efficiency of the three-way catalyst reactor is growing with torque value. The figures also shows that the efficiency of the TWC is very high in all range of engine's loads at $2500 \mathrm{rpm}$. In the highest value of torque $(80 \mathrm{Nm})$ it is almost $99 \%$. The efficiency of the catalytic reactor increases with the torque at constant rotation speed because the higher load, the higher temperature of combustion of the fuel and higher temperature of exhaust (and the TWC simultaneously). In higher temperature of combustion there is less hydrocarbons in exhaust and also the efficiency of the TWC is growing. Disturbances of that trend are observed in several points of engine's work: at torque 0 and $10 \mathrm{Nm}$ and also at 40 and 50 $\mathrm{Nm}$. In the first case (at 0 and $10 \mathrm{Nm}$ ) the likely reason was cooling the TWC reactor in low value of torque. Before the measurements the engine was warmed up at $10 \mathrm{Nm}$ for about 30 minutes. Next, the torque was lowered to 0 and waited about 10 minutes. In this time and during the measurement without load the temperature of the exhaust decreased and the TWC cooled down as well. Due to these events, the temperature of TWC during the measurement at $10 \mathrm{Nm}$ could be lower than at $0 \mathrm{Nm}$, because at $0 \mathrm{Nm}$ torque the TWC didn't cool down after heating up the engine.

In the second case, the reason of decreasing of the TWC efficiency could be disintegration of the higher hydrocarbons in the reactor and increasing of amount of lower hydrocarbons (such as BTX). Oxidation of the hydrocarbons, same as combustion of fuel in the combustion chamber occurs as many chain chemical reactions. It means that firstly the higher hydrocarbons are oxidized to lower ones and only in the final stage to carbon dioxide. In this regard TWC was working with high efficiency and reducing the higher hydrocarbons. Summarizing, obtained results showed that analysed catalytic reactor works well with high efficiency in measured range of engine's work.

\section{Nomenclature}

VOC volatile organic compounds

TWC three-way catalytic converter

BTX benzene, toluene, xylenes

\section{Bibliography}

[1] YUE, T., YUE, X., CHAI, F. et al. Characteristics of volatile organic compounds (VOCs) from the evaporative emissions of modern passenger cars. Atmospheric Environment. 2017, 151, 62-69.

[2] MERKISZ, J. Wpływ motoryzacji na skażenie środowiska naturalnego. Wydawnictwo Politechniki Poznańskiej. Poznań, 1993.

[3] CHŁOPEK, Z. Ochrona środowiska naturalnego. Pojazdy samochodowe. Wydawnictwa Komunikacji $i$ Łaczności. Warszawa, 2002.

[4] KAŹMIERCZAK, A. Silniki pojazdów samochodowych. Podręcznik do nauki zawodu Technik pojazdów samochodowych, Wydawnictwo REA. Warszawa, 2010.

[5] CARTER, W.P.L. Development of ozone reactivity scales for volatile organic compounds. Journal of the Air and Waste Management Association. 1994, 44, 881-899.
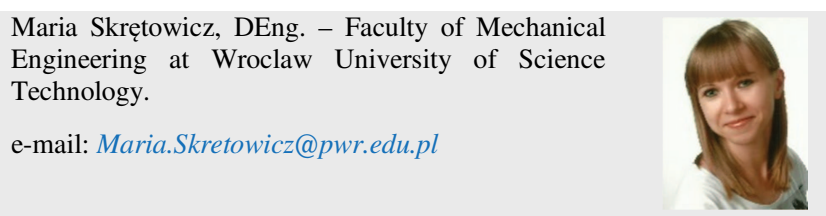

Radoslaw Wróbel, DEng. - Faculty of Mechanical Engineering at Wroclaw University of Science Technology.

e-mail: Radoslaw.Wrobel@pwr.edu.pl
[6] ODUM, J.R., HOFFMANN, T., BOWMAN, F.A. et al. Gas/particle partitioning and secondary organic aerosol yields. Environmental Science and Technology. 1996, 30, 2580-2585.

[7] Główny Urząd Statystyczny, Departament Badań Regionalnych i Środowiska: Ochrona Środowiska 2014. Informacje i opracowania statystyczne, Warszawa, 2014; materiał dostępny na stronie internetowej: www.stat.gov.pl.

[8] LIU, F.F., PENG, C., NG, J.C. BTEX in vitro exposure tool using human lung cells: trips and gains. Chemosphere. 2015, 128, 321-326.

[9] JANICKA, A. Ocena toksyczności mikroatmosfery środowiska wnętrza pojazdu samochodowego. Oficyna Wydawnicza Politechniki Wrocławskiej, 2013.

[10] MIZERSKI, W., Tablice chemiczne, wyd. piąte zaktualizowane. Wydawnictwo Adamantan. Warszawa, 2008.

[11] MERKISZ, J., Ekologiczne aspekty stosowania silników spalinowych. Wydawnictwo Politechniki Poznańskiej, Poznań, 1994.
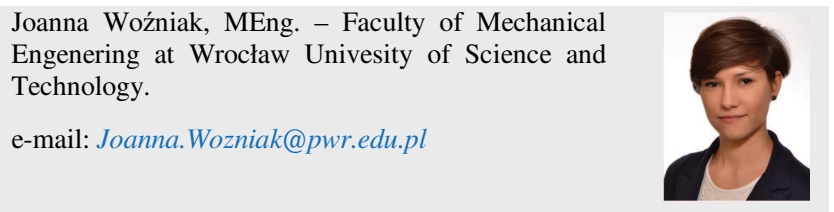